\title{
Assessment on the Relationship of the Effectiveness of the Gender and Development (GAD) Programs on the Teachers' Attitudes and Perceptions Concerning Gender-Related Issues: A Proposed Action Plan
}

\author{
Marilou Cabillo-Jimenez \\ School of Advanced Studies, The National Teachers College \\ E-mail: mariloucjimenez@gmail.com
}

\begin{abstract}
This study was intended to assess the effectiveness of Gender and Development (GAD) programs of the Division of City Schools-Manila and the perceptions and attitudes of the teachers. This study used the descriptivecorrelational study to test the relationship of perceptions and attitudes of the respondents on gender- related issues such as gender gap, gender inequality, sexual harassment, gender in curriculum, and gender stereotypes and the GAD programs of the DCS-Manila. The participants in this study were the Social Studies teachers in DCS-Manila. The research survey-questionnaire was the primary instrument used, which was undergone modifications from the experts. One (1) from the Division of City Schools-Manila's GAD Focal Point System, another, from the Principal of Tondo High School and the Former member of DCS-Manila GAD Coordinators, and lastly, personnel from the Philippine Commission of Women (PCW) before it was distributed to the respondents. After the full implementation of the study, the data gathered was analyzed and interpreted using Pearson-r to determine the significant relationship of GAD Programs of the DCS-Manila and the perceptions and attitudes of the teachers on gender-related issues. The Social Studies teachers assessed the GAD programs of the DCS- Manila and it was revealed to as effective. Regarding on the perceptions on gender-related issues, it was shown that they are aware and knowledgeable about the existing issues in schools. Moreover, the attitudes of the teachers on the gender-related issues are said to be highly positive. However, the results of the testing of relationship of GAD programs and the perceptions and attitudes of the respondents have acquired a low correlation, this means that the GAD programs are effective but limited to the improvement of awareness and point of views of the respondents regarding the gender-related issues.

Therefore, the researcher intended to propose a GAD program that is designed to address the different practices of teachers and schools with gender-related issues in the Division of City Schools-Manila. Moreover, the proposed program can be applied also to all schools of different Divisions in the Philippines to increase the level of perceptions and attitudes of the teachers about the Gender and Development. The program also gives ideas on how to improve the best practices to abolish the gender-related issues found in school.
\end{abstract}

Keywords: Gender and Development (GAD), Gender equality, Gender sensitivity, Gender empowerment, Gender issues, Gender mainstreaming, Gender stereotypes

DOI: $10.7176 / \mathrm{JEP} / 12-23-02$

Publication date:August $31^{\text {st }} 2021$

Women's rights are human rights, and every state should intensify its efforts to fulfill the duties and responsibilities of recognizing every woman in the society. Many believe in the idea that woman is an important agent to achieve sustainable development of one's nation and the state has a huge responsibility to help its women become agents of their goal. All nations are aiming for development, yet less effort on women's welfare in fact, it has ignored and harmed women in many ways (Torres et al., 1994). In the late 1960's and 1970's, the world was focused mainly on men while the women in general were the least priority. During the Second World War, feminism became rampant where many of the advocates were persistent to ensure that the right to gender equality is not only understood solely by mind but by the entire human empathy. Thus, people of the state shared the same value of respect and protect equality for all (Pananaw, 2007). Many studies have been done to justify the importance of women's participation on sustainable development. Maniquis (2005) explained that through the understanding of the equality between men and women, development can be attained. However, development has a gender dimension that was not recognized until recently. Because men were perceived as dominant in the productive sphere, and because of secondary importance given to reproductive functions, men's needs and concerns became the focus of development initiatives, with the assumption that these concerns apply to all.

Some advocates sought to find the answer on gender disparity where it became the world's greatest battle. Research in relation to gender equality and the uprising of the rights of women have been done. Gender equality is achieved when men and women enjoy the same rights and opportunities given by all sectors of society, including economic and political participation, and decision-making. In 1948, the United Nations General Assembly created the Universal Declaration of Human Rights (UDHR) which envisioned an equal treatment to 
all men and women in all aspects of society and be free from all forms of discriminations (including sex, races, status, roles etc.). The said declaration is a milestone document in the history of human rights and became the universal standard of achievements of all people and all nations in the world.

People have witnessed the struggle of women in fighting with inequalities in the society that leads to the creation of different laws that protect women's rights. In this sense, the United Nations adapted the Convention on Elimination of All Forms of Discriminations against Women (CEDAW) in 1979, where it became an international bill of rights for women on September 3, 1981. Such legislation and affirmative action policies have been a big impact to the changes in society. In 1995, the Fourth World Conference on Women held in Beijing, China became an inspiration for women's legislation in the world. It was principally initiated by the United Nations which produced a declaration of the international community's commitment to the advancement of women and a platform of action that set out measures for action by 2000 (GMMP, 2010).

Seemingly, the Philippines as one of the active members of UN, adopted all its provisions, and the government's effort is very visible to eradicate inequalities or discriminations among men and women, most especially in the field of education. In the Philippine context, the government has expressed its commitment for the first time to uplift women in the society. In the mid-seventies, the Philippine government responded to the UN's declaration of International Women's Year (1975) and the Decade for Women (1976-1985) with the creation of the National Commission on the Role of Filipino Women (NCRFW) (or Philippine Commission on Women in the present time), acting as the state machinery to make plans and policies concerning women (Torres \&amp; del Rosario, 1994). Former President Corazon C. Aquino issued the Executive Order No. 348, known as "The Philippine Development Plan for Women" in February 1989 to comply with the said state- organization. It provides a framework for the development of women in personal, family, economic, political, and socio-cultural and other legal spheres. Also, in 1995, Executive No. 273 or also known as "The Philippine Plan for Gender and Development" (1995-2025) was approved and adopted by former President Fidel V. Ramos. It is a National Plan that addresses, provides, and pursues full equality and development for men and women. It is the successor of the Philippine Development Plan for Women (1989-1992). In 2009, the government enacted the Republic Act No. 9710, also known as "The Magna Carta of Women," which will recognize the economic, political, and socio-cultural rights of women. This the most fundamental human rights document of the Philippine government that seeks to eliminate all forms of discriminations against women.

Equality between men and women signifies that the interests and needs of both women and men are taken into consideration. Regardless of gender, both are important elements in attaining development (Gumba, 2013 in Sumadsad \&amp; Tuazon, 2016). Gender approaches emerged in the history that paved its way for the development of gender parity. The liberal approaches became dominant, including the Women in Development (WID), Women and Development (WAD), and Gender and Development (GAD). The Women in Development approach was the first contemporary movement to specifically integrate women to development in a broader sense.

In this study, the researcher examined the theory of individualist feminism. This view holds the idea that every individual has equal rights. Specifically, it opposes the studies under the views of liberal feminism and radical feminism which encourages every woman to be firm in their own lives. In relation to the Gender and Development, the GAD approach has become dominantly acceptable in terms of gender equality. The Gender and Development (GAD) approach focuses on the equalities of men and women and the challenge to abolish the existing gender roles and relations. The major contributors of this approach are the writings of Oakley (1972) and Rubin (1975) who give more emphasis on the relationships of men and women in society. GAD is not concerned on women alone but how the society entrusts the roles and responsibilities to both men and women. GAD has significantly evolved in many ways and was adopted by different countries to uplift the participation of women in all areas of society. It is also used as a guide to successfully abolish the discriminations against men and women.

In lieu of this, the researcher focuses her study on the implementation of GAD programs in the Division of City Schools-Manila and how the teachers assess their perceptions and attitudes towards the said programs. A Memorandum Circular No. 2011 - 01 dated October 21, 2011, was released addressed to all Government Departments including their attached agencies, offices, bureaus, State Universalities and Colleges (SUCs), Government-Owned and Controlled Corporations (GOCCs) and all other government instrumentalities as their guidelines and procedures for the establishment, strengthening and institutionalization of the GAD Focal Point System (GFPS). Moreover, the Department of Education (DepEd) issued Guidelines on the Preparation of Gender and Development (GAD) Plans, Utilization of GAD Budgets and Submission of Accomplishment Reports (DepEd Order 63 series of 2012) that will require the government agencies, state universities and colleges (SUCs), government-owned and controlled corporations, local government units (LGUs) and other government instrumentalities to formulate their annual Gender and Development (GAD) Plans and Budgets. These guidelines on the utilization of GAD Budget and other requirements, would serve as a reference to all GAD Program implementers of DepEd. 


\subsubsection{Heading 3}

This study determined the status of the GAD Program of DepEd-Manila through the Input-Process-Output approach. The input is the assessment of teachers on GAD programs and perceptions and attitudes of teachers toward gender-related issues. The process is the validated questionnaires made by the researcher and the output is the proposed strategic plan to improve the GAD programs of DCS-Manila and the perceptions and attitudes of teachers towards gender-related issues.

This study aims to identify the effectiveness of GAD programs in the DCS-Manila. Specifically, this study answered the following questions:

1. What is the assessment of teachers on the effectiveness of GAD programs in terms of:

1.1. Gender mainstreaming mechanisms, and

1.2. GAD Plans and Activities?

2. What are the attitudes and perceptions of teachers on the following gender-related issues:

2.1. Gender stereotype,

2.2. Gender gap,

2.3. Gender inequality,

2.4. Gender biased on curriculum and instructions, and

2.5. Sexual Harassment?

3. Is there a significant relationship between the assessment of GAD programs and the attitudes and perceptions of teachers on the gender-related issues?

4. What strategic plan can be proposed to improve:

4.1. The GAD programs in the Division of City Schools-Manila, and

4.2. The attitudes and perceptions of teachers on gender-related issues?

Hypothesis of the Study

This study will test the null hypothesis of the problem. Using data gathering and statistical treatment, a decision will be made whether to accept or reject the following hypotheses:

Ho. There is no significant relationship between the assessment of GAD programs and the attitudes and perceptions of teachers on the gender-related issues.

\section{SCOPE AND DELIMITATION OF THE STUDY}

This study is mainly concerned with the assessment of teachers on GAD programs of their school and its effects on their attitudes and perceptions on gender-related issues. The researcher will conduct the study in selected schools in the Division of City Schools-Manila through the fishbowl technique. The participants or subjects of the study are 190 Social Studies teachers. The study will run through the school year 2018-2019.

The researcher chose the Social Studies teachers because she believes that the teachers from Social Studies department have enough background and knowledge on the Gender and Development (GAD) and gender-related issues. Moreover, it is related to the matter of the subject of the Social Studies teachers specially in Grade 10 teachers. Because of the sampling method to be used by the researcher, the scope of the study is limited to the number of participants that supposedly represent the whole population needed in the present study which may affect the findings.

At the end of the study, the researcher proposed a strategic plan to improve the GAD programs and the perceptions and attitudes of the teachers regarding gender-related issues that will be beneficial both to students and teachers in school and to the school administrators and DepEd monitoring officials. However, the researcher also believes that it may not cater the whole Division of Manila because it can be applied to some schools which cannot be to others. The researcher wishes to make the proposed matrix be a basis for improving GAD programs in all schools in Manila that will help to raise awareness regarding Gender and Development and abolish gendered issues in schools.

\section{SUMMARY OF FINDINGS}

After gathering, presenting, analyzing, and interpreting the data, the following findings were drawn:

1. What is the assessment of teachers on the effectiveness of GAD programs in terms of:

1.1. Gender mainstreaming mechanisms

The teachers assessed the GAD programs in the Division of City Schools-Manila in terms of Gender Mainstreaming Mechanisms as effective with the overall mean of 4.12 and a standard deviation of 0.83 . Moreover, it was found out that most of the teachers agreed that all Gender Mainstreaming Mechanisms of different schools are effective.

1.2. GAD Plans and Activities

It was found out that most of the teachers' assessment on the implementation of the GAD programs in the Division of City Schools-Manila in terms of GAD Plans and Activities is effective with a weighted mean of 3.76 and standard deviation of 1.02. Thus, all the indicators pertaining to the programs are said to be effective. 
2. What are the attitudes and perceptions of teachers on the following gender-related issues:

2.1. a. Perception on Gender Stereotype

It revealed that most of the selected Social Studies teachers in the Division of City Schools-Manila are moderately agree on the Gender Stereotype which indicates that they have an average level of perception towards the different gender related issues involving gender stereotyping having a weighted mean of 3.33 and standard deviation of 1.23 .

2.1. b. Attitudes on Gender Stereotype

The over-all weighted mean of the teachers' attitude regarding the Gender Stereotype is 4.59 with a computed standard deviation of 0.78 in the Division of City Schools-Manila and with interpretation of strongly agree.

2.2. a. Perception on Gender Gap

The perception of the Social Studies teachers on gender-related issues in terms of gender gap garnered a weighted mean of 2.97 and Standard Deviation of 1.21 with interpretation of moderately agree.

2.2. b. Attitude on Gender Gap

The attitude of the Social Studies teachers on gender-related issues in terms of gender gap has a weighted mean of 4.38 and standard deviation of 0.90 with verbal interpretation of Agree.

2.3. a. Perception on Gender Inequality

The attitude of the Social Studies teachers in the Division of City Schools-Manila on gender related issues in terms of perception on gender inequality has an over-all mean score of 3.21 and SD of 1.19 with verbal interpretation of moderately agree.

2.3. b. Attitude on Gender Inequality

The attitude of the Social Studies teachers in the Division of City Schools-Manila on gender-related issues in terms of gender inequality has garnered a weighted mean of 4.36 with a computed Standard Deviation of 0.84 and has a verbal interpretation of Agree.

2.4. a. Perception on Gender biased on curriculum and instructions

The perception of Social Studies teachers in the DCS-Manila on gender related issues in terms of gender-biases on curriculum and instructions has 3.79 of weighted mean and standard deviation of 0.98 and verbal interpretation of Agree.

2.4. b. Attitude on Gender biased on curriculum and instructions

The attitude of selected Social Studies teachers in the DCS-Manila on gender related issues in terms of gender biased on curriculum and instructions has a weighted mean of 4.36 and standard deviation of 0.84 with a verbal description of Agree.

2.5. a. Perception on Sexual Harassment

The perception of Social Studies teachers on gender related issues in the DCS-Manila in terms of sexual harassment has found out to as Moderately Agree with a weighted mean of 2.67 and standard deviation of 1.34.

2.5. b. Attitude on Sexual Harassment

The attitude of respondents on gender related issues in terms of sexual harassment computed a weighted mean of 4.22 and Standard Deviation of 0.8 with verbal interpretation of Agree.

3. Is there a significant relationship between the assessment of GAD programs and the attitudes and perceptions of teachers on the gender-related issues?

It was found out that there is very weak significant relationship between the GAD programs in terms of Gender Mainstreaming Mechanisms and the perceptions and attitudes of the respondents in terms of Gender-related issues. Therefore, the decision made was to reject the null hypothesis and accept the alternative.

On the other hand, it was found out also that there is a significant moderate correlation between the GAD programs specifically, the GAD Plans and Activities, and the perception and attitude of the respondents on the different gender related issues. This implies that the Gender and Development Plans and Activities are effective and has an impact in raising the awareness of teachers in the Division of City Schools-Manila regarding the Gender-related Issues. It was found out too that there is a significant relationship between the GAD Programs and Gender-related Issues. So, the decision made was reject the null hypothesis and accept the alternative hypothesis which stated as there is no significant relationship between the assessment of GAD programs and the attitudes and perceptions of teachers on the gender-related issues.

4. What strategic plan can be proposed to improve:

4.1. The GAD programs in the Division of City Schools-Manila

The GAD programs of the Division of City Schools-Manila are found out effective and has a direct impact on raising the awareness of the teachers regarding Gender and Development and to the gender-related issues in schools. As a result, a strategic plan was proposed by the researcher.

4.2. The attitudes and perceptions of teachers on gender-related issues?

The perceptions and attitudes of the Social Studies teachers in the Division of City Schools-Manila on genderrelated issues were found positively well. To establish a stronger attitudes and perceptions towards the genderrelated issues in school, the researcher came up with a proposed strategic plan. 


\section{CONCLUSIONS}

Based on the findings mentioned in this above, the researcher came up with the following conclusions:

1. The GAD programs in the Division of City Schools-Manila found effective however, not enough to solve the common issues regarding gender.

2. The respondents have awareness on the gender-related issues and willing to integrate the knowledge they acquired to promote gender equality inside the school and classroom.

3. The over-all attitude of the Social Studies teachers in the Division of City Schools-Manila regarding the gender-related issues was strongly positive. However, the findings shows that most of the teacher-respondents were agree that the sexual harassment are not totally encountered, it is important to know the capabilities of schools to handle such issues.

4. The GAD programs have an impact in the perception and attitude of the teachers. The programs can help to raise awareness and improve the point of view of the teachers regarding the gender equality and genderrelated issues.

5. There is a significant relationship between the GAD programs in terms of Gender Mainstreaming Mechanisms and the GAD Plans and Activities and the gender-related issues specifically the gender Stereotype, Gender Gap, Gender Inequality, Gender Bias in curriculum and instruction, and Sexual Harassment.

6. There is a need for improving the GAD programs in the Division of City Schools-Manila and the monitoring of these programs.

7. There is a need for strategic plan to improve GAD programs in the DCS-Manila and the perception and attitude of the teachers regarding gender-related issues.

Proposed Strategic GAD Programs

After analyzing the result of the findings, the researcher come up with a proposed strategic GAD Programs as an intervention to create or impose awareness to school personnel and students regarding the importance of Gender and Development (GAD) in school and as well as to help the GAD implementers of DepEd in designing a programs that promote gender equality. Moreover, this strategic proposal aims to increase the level of perceptions and attitudes of the teachers on GAD programs and gender-related issues existing in school.

This matrix is only a proposal and subject for approval that will initiate a gender-fair school environment in the Division of City Schools-Manila. It can be used by other schools outside the DCS-Manila as a guide in determining the strengths and weaknesses of their programs regarding GAD and establishing an intervention analysis to improve the weakness areas. Hence, it can be useful and applicable to all schools that need to raise awareness regarding gender parity and GAD.

I. Objectives

The main objective of this proposed matrix is to help the school administrators, teachers, students, and community to raise their awareness on Gender and Development (GAD) and improve their perception and attitude toward gender-related issues. It covers the schools from Division of City Schools-Manila.

Moreover, this matrix wishes to ensure that gender equality and women's human rights are fully incorporated into Programs, Plans, and Activities (APPs) of schools as well as in its Annual Improvement Plan (AIP), School Improvement Plan (SIP), and Continuum Improvement Plan (CIP) that will support women empowerment.

II. Rationale

The 10-year review of the Beijing Platform for Action (New York, 2005) declared that commitments to gender equality were not matched by consistent implementation. Specifically, commitments to gender equality have not been supported financially by national government budgets or through official development assistance. This strategic matrix plan is designed to address this problem.

Pursuant to the Magna Carta of Women and the Philippine GAD Agenda the Division of City SchoolsManila is required to set up a strategic plan to combat the issues regarding GAD. Through different memorandum issued by the Division, the school is authorized to follow the guidelines to improve the visibility of Gender and Development (GAD) and taking seriously the women empowerment.

However, many hindrances and limitations on the GAD programs are facing by the different schools in the country which affect the awareness and attitude of the teachers and the students. These factors should be the focus of the governing authorities to comply with the needs to address issues concerning gender. By constantly planning, monitoring, and evaluating the different GAD programs of schools, we can eliminate the genderrelated issues existing. The teachers and the school administrators have the vital role in achieving the GAD's goal as part of the national sustainable development programs.

In line with this, the proposed strategic plan was made to address the different problems concerning GAD and intervention activities to help the school to eliminate these gender-related issues. It will serve as a guide for planning, monitoring, and evaluating the GAD programs in schools.

III. Parts of the Matrix Plan

\section{GAD Objectives}

This will be the goals of the activities being recommended for the issues that wants to resolve. And help 
the implementers in guiding which activities best suit for certain gender-related issues.

2. Client Focused

This is the part of the plan that will serve as the primary beneficiaries of the designed activities. Also, they are the main focus of the plan for they will be the keys to identify if the plans and activities are effective in promoting GAD and avoid gender-related issues. The client focused is composed of teachers, students, school administrators, communities, and other concern governing agencies like DepEd and PNP.

3. Issue Wants to Resolve

This will be the reason behind for developing this matrix. Issues are going to be solved by the different activities given that serve as interventions.

4. Recommended Activity and Duration

The recommended activity is the designed intervention for the identified issues in school with specified duration. This will be the guiding tool to effectively eliminate the issues found in schools and could help the teachers and students to raise awareness and attitude towards gender-related issues. Likewise, on the part of the school administrators, this could help them to analyze and evaluate the results after applying the recommended activities.

5. Proposed Budget

The proposed budget for the different activities is mainly come from the Maintenance and Other Operating Expenses (MOOE) of the school. In pursuant to the Joint Circular 2012-01 or the Guidelines for the Preparation of Annual Gender and Development (GAD) Plans and Budgets and Accomplishment Reports to Implement the Magna Carta of Women issued by the Philippine Commission on Women (PCW) the Department of Education (DepEd) issued the DO 63 s. 2012 or Guidelines on the Preparation of Gender and Development (GAD) Plans, Utilization of GAD Budgets and Submission of Accomplishment Reports. The costing or allocating budget for GAD Plans may be in the form of a separate GAD fund to support the PPAs; as integrated in major programs and projects (PPAs); or as counterpart fund from the official development assistance (ODA) for ODA-funded projects. It is understood that the GAD Budget does not constitute an additional budget over an agency's total budget appropriations, nor a separate five percent (5\%) taken from the total agency budget is readily available. The approved issue-based programs, projects and activities arising from research and gender analysis, determine the annual GAD Budget.

From this, the matrix has a total budget of Php 140,000.00 but subject for approval and changes. The proposed budget plan can be allocated differently based on the capacity of the school funds.

6. Estimated Result

The estimated result is the expected outcome of the recommended activities. This is the tool to measure if the recommended activities are effective in giving aid and answered the issues found existed in school.

\begin{tabular}{|c|c|c|c|c|c|}
\hline $\begin{array}{c}\text { GAD Objectives } \\
\text { (1) }\end{array}$ & $\begin{array}{c}\text { Client Focused } \\
\text { (2) }\end{array}$ & $\begin{array}{c}\text { Issue Wants to } \\
\text { Resolve } \\
\text { (3) }\end{array}$ & $\begin{array}{l}\text { Recommended } \\
\text { Activity and } \\
\text { Duration } \\
\text { (4) }\end{array}$ & $\begin{array}{l}\text { Proposed } \\
\text { Budget } \\
\text { (5) }\end{array}$ & $\begin{array}{l}\text { Estimated } \\
\text { Result } \\
\text { (6) }\end{array}$ \\
\hline $\begin{array}{l}\text { To ensure the } \\
\text { inclusion of both } \\
\text { women and men in } \\
\text { national } \\
\text { development }\end{array}$ & $\begin{array}{l}\text { Students, } \\
\text { Teachers, Focal } \\
\text { Point System, } \\
\text { School } \\
\text { Administrators, } \\
\text { and Staff }\end{array}$ & $\begin{array}{l}\text { The prevalent } \\
\text { inequalities, and } \\
\text { gender gap } \\
\text { between and } \\
\text { among men and } \\
\text { women in school }\end{array}$ & $\begin{array}{l}\text { The celebration of } \\
\text { Local Women's } \\
\text { Month and National } \\
\text { Day of Women by } \\
\text { giving tribute and } \\
\text { appreciation for all } \\
\text { women teachers, } \\
\text { students, and staff } \\
\text { who gave } \\
\text { extraordinary effort } \\
\text { in their fields } \\
\text { (During March). }\end{array}$ & $\begin{array}{l}\text { From } \\
\text { MOOE }\end{array}$ & $\begin{array}{l}\text { Improved level } \\
\text { of awareness } \\
\text { of students, } \\
\text { teachers, } \\
\text { Administrators } \\
\text { about women } \\
\text { empowerment } \\
\text { and } \\
\text { belongingness. }\end{array}$ \\
\hline
\end{tabular}




\begin{tabular}{|c|c|c|c|c|c|}
\hline $\begin{array}{l}\text { GAD Objectives } \\
\text { (1) }\end{array}$ & $\begin{array}{c}\text { Client Focused } \\
\text { (2) }\end{array}$ & $\begin{array}{c}\text { Issue Wants to } \\
\text { Resolve } \\
\text { (3) }\end{array}$ & $\begin{array}{l}\text { Recommended } \\
\text { Activity and } \\
\text { Duration } \\
\text { (4) }\end{array}$ & $\begin{array}{l}\text { Proposed } \\
\text { Budget } \\
\text { (5) }\end{array}$ & $\begin{array}{l}\text { Estimated } \\
\text { Result } \\
\text { (6) }\end{array}$ \\
\hline $\begin{array}{l}\text { To promote and } \\
\text { inculcate the basic } \\
\text { Human Rights in } \\
\text { students and } \\
\text { teachers as part of } \\
\text { the compliance to } \\
\text { Human Rights } \\
\text { Education }\end{array}$ & $\begin{array}{l}\text { Students, } \\
\text { teachers, } \\
\text { Administrators }\end{array}$ & $\begin{array}{l}\text { The lack of } \\
\text { background in } \\
\text { basic Human } \\
\text { Rights of } \\
\text { teachers and } \\
\text { students that lead } \\
\text { to violence. } \\
\text { The Human } \\
\text { Rights Education } \\
\text { in the Philippines } \\
\text { is not manifested } \\
\text { in some schools. }\end{array}$ & $\begin{array}{l}\text { Providing a } \\
\text { tarpaulin that shows } \\
\text { the value of Basic } \\
\text { Human Rights and } \\
\text { appreciating } \\
\text { everyone's } \\
\text { uniqueness. } \\
\text { Distributing } \\
\text { modules and flyers } \\
\text { that indicates } \\
\text { information about } \\
\text { Human Rights } \\
\text { Education. } \\
\text { Celebrating the } \\
\text { Human Rights Day } \\
\text { (During December } \\
\text { 10). }\end{array}$ & $\begin{array}{l}10,000 \\
\text { From } \\
\text { MOOE }\end{array}$ & $\begin{array}{l}\text { Raised } \\
\text { awareness and } \\
\text { give } \\
\text { importance } \\
\text { about basic } \\
\text { Human Rights } \\
\text { to students and } \\
\text { teachers. } \\
\text { Improved the } \\
\text { manifestations } \\
\text { of Human } \\
\text { rights in } \\
\text { Education in } \\
\text { some schools. }\end{array}$ \\
\hline $\begin{array}{l}\text { To protect the } \\
\text { women and } \\
\text { children in all } \\
\text { forms of abuse }\end{array}$ & $\begin{array}{l}\text { Students, } \\
\text { Teachers, Focal } \\
\text { Point System, } \\
\text { School } \\
\text { Administrators, } \\
\text { Staff, and } \\
\text { Philippine } \\
\text { National Police }\end{array}$ & $\begin{array}{lr}\text { The } & \text { large } \\
\text { number } & \text { of } \\
\text { reported } & \\
\text { incidents } & \text { of } \\
\text { abused women } \\
\text { and children in } \\
\text { the country. }\end{array}$ & 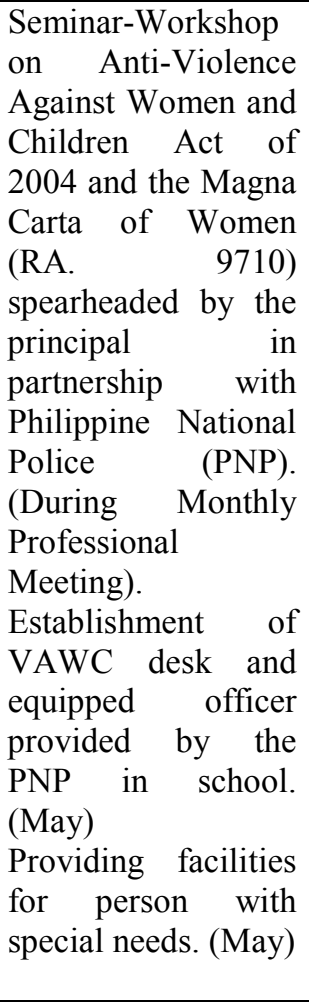 & $\begin{array}{l}\text { From } \\
\text { MOOE }\end{array}$ & 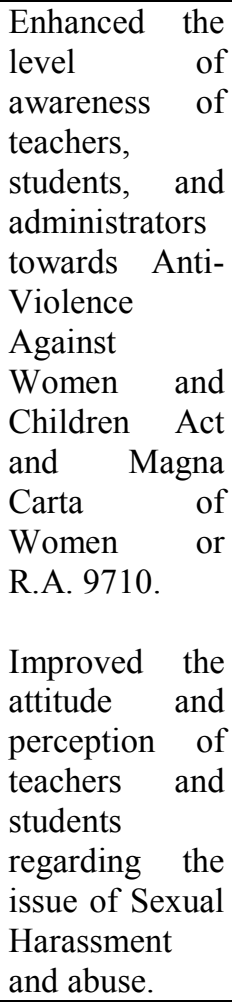 \\
\hline
\end{tabular}




\begin{tabular}{|c|c|c|c|c|c|}
\hline $\begin{array}{c}\text { GAD Objectives } \\
\text { (1) }\end{array}$ & $\begin{array}{c}\text { Client Focused } \\
\text { (2) }\end{array}$ & $\begin{array}{c}\text { Issue Wants to } \\
\text { Resolve } \\
\text { (3) }\end{array}$ & $\begin{array}{c}\text { Recommended } \\
\text { Activity and } \\
\text { Duration } \\
\text { (4) }\end{array}$ & $\begin{array}{l}\text { Proposed } \\
\text { Budget } \\
\text { (5) }\end{array}$ & $\begin{array}{l}\text { Estimated } \\
\text { Result } \\
\text { (6) }\end{array}$ \\
\hline $\begin{array}{l}\text { To improve the } \\
\text { level of awareness } \\
\text { of teachers } \\
\text { regarding the } \\
\text { Gender } \\
\text { Development and } \\
\text { (GAD) as they } \\
\text { serve a vital role in } \\
\text { promulgating the } \\
\text { GAD programs in } \\
\text { school }\end{array}$ & $\begin{array}{l}\text { Teachers, Focal } \\
\text { Point System } \\
\text { and } \quad \text { School } \\
\text { Administrators }\end{array}$ & $\begin{array}{l}\text { The low level of } \\
\text { awareness of } \\
\text { teachers } \\
\text { regarding GAD } \\
\text { programs and } \\
\text { inadequate } \\
\text { trainings in } \\
\text { coping up with } \\
\text { issues regarding } \\
\text { gender. }\end{array}$ & $\begin{array}{l}\text { Providing a capacity } \\
\text { building activity to } \\
\text { every teacher to be } \\
\text { equipped, improved, } \\
\text { and enhanced } \\
\text { knowledge } \\
\text { regarding the } \\
\text { gender-related } \\
\text { issues in school in } \\
\text { partnership with } \\
\text { other governing } \\
\text { agencies; } \\
\text { Providing a Gender } \\
\text { and Development } \\
\text { Team Building } \\
\text { Activity outside the } \\
\text { school (During first } \\
\text { week of April). } \\
\text { Personality } \\
\text { Development and } \\
\text { Seminar (During In- } \\
\text { Service Training/ } \\
\text { Last week of } \\
\text { October) }\end{array}$ & $\begin{array}{l}\text { May be } \\
\text { provided } \\
\text { by the } \\
\text { teachers } \\
\text { or } \\
\text { through } \\
\text { school } \\
\text { activities }\end{array}$ & $\begin{array}{l}\text { Improved level } \\
\text { of awareness } \\
\text { of teachers } \\
\text { regarding the } \\
\text { Gender and } \\
\text { Development } \\
\text { (GAD) } \\
\text { programs and } \\
\text { gender-related } \\
\text { issues in } \\
\text { school. }\end{array}$ \\
\hline $\begin{array}{l}\text { To integrate and } \\
\text { improve the } \\
\text { Programs, Plans } \\
\text { and Activities } \\
\text { (PPAs) regarding } \\
\text { GAD in the AIP, } \\
\text { SIP and CIP of } \\
\text { school pursuance } \\
\text { to Republic Act } \\
\text { No. } 9155 \text { or known } \\
\text { as Governance of } \\
\text { Basic Education } \\
\text { Act of } 2001 \text { to help } \\
\text { schools reach the } \\
\text { goal of providing } \\
\text { access to quality } \\
\text { education. }\end{array}$ & $\begin{array}{l}\text { School } \\
\text { Administrators, } \\
\text { Focal Point } \\
\text { System, and } \\
\text { teachers }\end{array}$ & $\begin{array}{l}\text { Lacking visibility } \\
\text { of GAD in the } \\
\text { AIP, SIP and } \\
\text { CIP; } \\
\text { Lacking desired } \\
\text { activities and } \\
\text { programs of } \\
\text { school regarding } \\
\text { GAD }\end{array}$ & $\begin{array}{l}\text { Revisiting the } \\
\text { School } \\
\text { Improvement Plan } \\
\text { (SIP) Guidebook } \\
\text { involving the } \\
\text { teachers, staff and } \\
\text { school head by } \\
\text { using the enhanced } \\
\text { planning process in } \\
\text { these guidelines } \\
\text { (During January, the } \\
\text { start of SIP cycle); } \\
\text { Through the } \\
\text { guidebook, the } \\
\text { school may update } \\
\text { their current Annual } \\
\text { Improvement Plan } \\
\text { (AIP) and } \\
\text { Continuum } \\
\text { Improvement Plan } \\
\text { (CIP) during the } \\
\text { Learning Action } \\
\text { Cells (LAC Session) } \\
\text { (Every Month). }\end{array}$ & N/A & $\begin{array}{l}\text { The enhanced } \\
\text { GAD programs } \\
\text { included in the } \\
\text { AIP, SIP, and } \\
\text { CIP. } \\
\text { Determined } \\
\text { weaknesses } \\
\text { and strengths } \\
\text { of Programs, } \\
\text { Plans, and } \\
\text { Activities } \\
\text { (APPs) and } \\
\text { provided } \\
\text { intervention. } \\
\text { The teachers } \\
\text { acquired } \\
\text { knowledge on } \\
\text { how to do SIP, } \\
\text { AIP, and CIP } \\
\text { of school with } \\
\text { GAD which } \\
\text { increased their } \\
\text { feeling of } \\
\text { belongingness } \\
\text { and self-worth. }\end{array}$ \\
\hline
\end{tabular}




\begin{tabular}{|c|c|c|c|c|c|}
\hline $\begin{array}{c}\text { GAD Objectives } \\
\text { (1) }\end{array}$ & $\begin{array}{c}\text { Client Focused } \\
\text { (2) }\end{array}$ & $\begin{array}{c}\text { Issue Wants to } \\
\text { Resolve } \\
\text { (3) }\end{array}$ & $\begin{array}{c}\text { Recommended } \\
\text { Activity and } \\
\text { Duration } \\
\text { (4) }\end{array}$ & $\begin{array}{l}\text { Proposed } \\
\text { Budget } \\
\text { (5) }\end{array}$ & $\begin{array}{l}\text { Estimated } \\
\text { Result } \\
(6)\end{array}$ \\
\hline $\begin{array}{l}\text { To promote } \\
\text { gender-fair } \\
\text { education in school } \\
\text { and to eliminate } \\
\text { the gender biases } \\
\text { found in the } \\
\text { textbooks and } \\
\text { other learning } \\
\text { resources. } \\
\text { To establish a } \\
\text { teaching-learning } \\
\text { processes that is } \\
\text { free from gender- } \\
\text { related issues. }\end{array}$ & $\begin{array}{l}\text { Schools } \\
\text { Division Office } \\
\text { Personnel, } \\
\text { teachers, } \\
\text { students, school } \\
\text { head, and } \\
\text { department } \\
\text { heads. }\end{array}$ & $\begin{array}{l}\text { The prevalent } \\
\text { evidence of } \\
\text { gender biases in } \\
\text { the textbooks and } \\
\text { instructions of } \\
\text { teachers. }\end{array}$ & 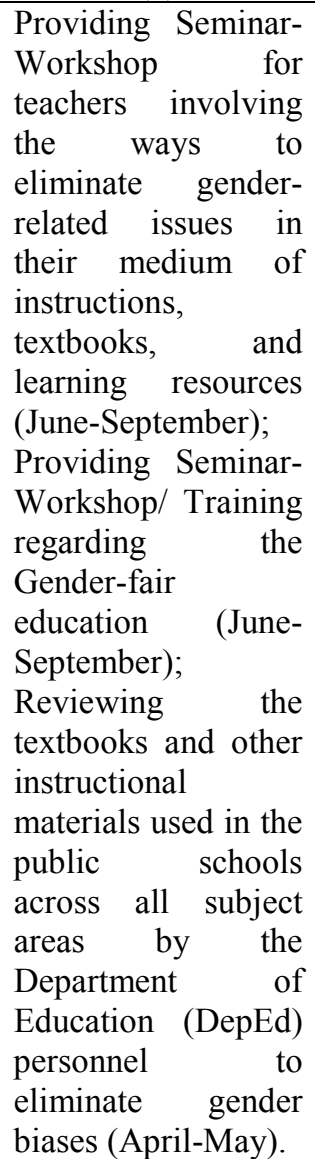 & $\begin{array}{l}\text { Provided } \\
\text { by the } \\
\text { Schools } \\
\text { Division } \\
\text { Office } \\
\text { (SDO) } \\
\text { N/A }\end{array}$ & $\begin{array}{l}\text { Improved } \\
\text { attitude and } \\
\text { perception of } \\
\text { teachers on } \\
\text { gender-related } \\
\text { issues. } \\
\text { The increased } \\
\text { of knowledge } \\
\text { of teachers } \\
\text { about in } \\
\text { combating the } \\
\text { gender-related } \\
\text { issues } \\
\text { school. } \\
\text { The revised } \\
\text { textbooks and } \\
\text { learning } \\
\text { materials that } \\
\text { promotes } \\
\text { gender-fair } \\
\text { education. }\end{array}$ \\
\hline $\begin{array}{l}\text { Appreciating the } \\
\text { uniqueness of all } \\
\text { genders in school } \\
\text { and to uplift the } \\
\text { confidence of all } \\
\text { students in school. }\end{array}$ & Students & $\begin{array}{l}\text { Issue of gender } \\
\text { gap in school } \\
\text { between men, } \\
\text { women, and } \\
\text { Lesbian, Gay, } \\
\text { Bisexual, and } \\
\text { Transgender } \\
\text { (LGBT) }\end{array}$ & $\begin{array}{l}\text { Holding a Gender } \\
\text { and Development } \\
\text { (GAD) Night in } \\
\text { exchange } \\
\text { traditional Junior- } \\
\text { Senior Prom to } \\
\text { appreciate and value } \\
\text { the presence of } \\
\text { LGBT community, } \\
\text { men and women in } \\
\text { school (During } \\
\text { February/March). } \\
\text { Providing } \\
\text { Orientation Seminar } \\
\text { for all students } \\
\text { regarding Sexual } \\
\text { Orientation, and } \\
\text { Gender Identity } \\
\text { Equality (SOGIE) } \\
\text { Bill (During } \\
\text { October } 11 \text { National } \\
\text { Day of LGBT). }\end{array}$ & 30,000 & $\begin{array}{l}\text { Developed } \\
\text { appreciation } \\
\text { for all genders } \\
\text { in school and } \\
\text { community. } \\
\text { Enhanced } \\
\text { awareness } \\
\text { about the } \\
\text { SOGIE, and } \\
\text { the rights of } \\
\text { the LGBT } \\
\text { people }\end{array}$ \\
\hline
\end{tabular}




\begin{tabular}{|c|c|c|c|c|c|}
\hline $\begin{array}{c}\text { GAD Objectives } \\
\text { (1) }\end{array}$ & $\begin{array}{c}\text { Client Focused } \\
\text { (2) }\end{array}$ & $\begin{array}{c}\text { Issue Wants to } \\
\text { Resolve } \\
\text { (3) }\end{array}$ & $\begin{array}{c}\text { Recommended } \\
\text { Activity and } \\
\text { Duration } \\
\text { (4) }\end{array}$ & $\begin{array}{l}\text { Proposed } \\
\text { Budget } \\
\text { (5) }\end{array}$ & $\begin{array}{l}\text { Estimated } \\
\text { Result } \\
\text { (6) }\end{array}$ \\
\hline $\begin{array}{l}\text { To disseminate } \\
\text { immediately the } \\
\text { information about } \\
\text { GAD and its } \\
\text { related activities to } \\
\text { all concerns for the } \\
\text { improvement of } \\
\text { proper } \\
\text { communication. }\end{array}$ & $\begin{array}{l}\text { Focal Point } \\
\text { System, } \\
\text { teachers, } \\
\text { students, school } \\
\text { head }\end{array}$ & $\begin{array}{l}\text { Due to the } \\
\text { improper way of } \\
\text { disseminating of } \\
\text { information } \\
\text { about GAD, the } \\
\text { concern people } \\
\text { are decreasing its } \\
\text { knowledge } \\
\text { towards GAD. } \\
\text { Lack of system } \\
\text { of informing the } \\
\text { school about } \\
\text { GAD related } \\
\text { activities and } \\
\text { programs. }\end{array}$ & $\begin{array}{l}\text { Creating a GAD } \\
\text { Core in school } \\
\text { where the GAD } \\
\text { activities, } \\
\text { announcements, and } \\
\text { vision and mission } \\
\text { were posted and } \\
\text { seen by all (June); } \\
\text { Creating Focal Point } \\
\text { System and Page in } \\
\text { social medias for } \\
\text { fast tracking of } \\
\text { information on } \\
\text { GAD (June); } \\
\text { Introducing the } \\
\text { GAD Core and } \\
\text { coordinators } \\
\text { composed of } \\
\text { teachers, students, } \\
\text { and Focal Point } \\
\text { System (During } \\
\text { Assembly time) }\end{array}$ & 20,000 & $\begin{array}{l}\text { Systematized } \\
\text { communication } \\
\text { process which } \\
\text { caters all the } \\
\text { persons } \\
\text { involve in the } \\
\text { APPs of } \\
\text { school. }\end{array}$ \\
\hline
\end{tabular}

\section{References}

A. Books

Asian Development Bank (ADB), (2013). The Gender Equality in the Labor Market in the Philippines. Asian Development Bank Publications. Philippines.

Illo, J. (2010). Harmonized Gender and Development (GAD) Guidelines (NEDA, PCW, ODA-GAD Network). National Economic Development Authority (NEDA). Quezon City, Philippines.

Meyer, R., (2010). Accounting for Gender Results: A Review of the Philippine GAD Budget Policy. Philippine Commission on Women (PCW). Philippines.

Gumba, B., (2013). Gender Equality in a Higher Educational Institution: A Case in the Philippines. Journal of Education, Arts and Humanities, Vol. 1 (3). Philippines.

Pimentel, M., (2014). Gender Fair Education (GFE): Teaching Gender Equality and Non Sexist Learning. Women and Gender Institute, Mirriam College. Philippines.

Tarrayo, V. (2014). Gendered Word (or World): Sexism in Philippine Preschool English Language Textbooks. Philippines.

Department for Children, Schools, and Families (2009). Gender Issues in School - What Works To Improve Achievement For Boys and Girls. ISBN: 978-1-84775-442-4 D16(8311)/0609/751. DCSF Publications. United Kingdom.

B. Theses/ Dissertations

Dimayuga, M. (2017). Gender and Development: Awareness and Extent of Participation on Gender and Development Programs Among DepEd Senior High School- Division of Tanauan City Personnel. Tanauan City, Philippines.

Gorospe, E. (2000). Evaluation of Gender and Development (GAD) in the Department of Education. Philippines.

Losaria, N. (2011). Evaluation of Gender and Development Program: Basis for the Proposed Enhanced Gender and Development Plan of the Department of Education. An Unpublished Thesis, Polytechnic University of the Philippines.

Natividad, R. (2015). Utilization of the Activity-Based Multi-Domain Learning in Reading Instruction: Basis for a Proposed Reading Intervention Program. Master of Arts in Education. The National Teachers College. Manila, Philippines.

Surmieda, N. (1998). Gender Education in Secondary Social Studies. Philippines. 


\section{JOURNALS/ ARTICLES}

Assadullah, N. (2018). Gender Stereotypes and Education: A Comparative Content Analysis of Malaysian, Indonesian, Pakistani, and Bangladesh School Textbooks. DOI: 10.1371/journal.pone.090807

Bandura, A. \& Bussey, K. (1999). Social Cognitive Theory of Gender Development and Differentiation. Psychological Review Vol 106, (4). Guilford Publications. New York, U.S.A

Bucoy, R. (2017). 5th Higher Education Summit on Gender Issues. Commission on Higher Education (CHED). Retrieved from https://ched.gov.ph/wp-content/uploads/2017/12/KEYNOTE.pdf

Duffie, V. (2016). Gender and Development. Development in an Unequal World 7th Edition. Retrieved from https://www.developmenteducation.ie/teachers-and-educators/transition-year/extraresources/Resources/8020-additional-resources/10.PDF

Ifegbesan, A. (2010). Gender-Stereotypes Belief and Practices in the Classroom: The Nigerian Post-Primary School Teachers'. Global Journal of Human Social Science Vol. 10 Issue 4(Ver. 1.0). Department of Curriculum Studies and Instructional TechnologyFaculty of EducationOlabisi Onabanjo University, AgoIwoyeOgun State, Nigeria

Jabeen, S., et al. (2014). Gender Discrimination in Curriculum: A Reflection from Punjab Textbook Board. Bulletin of Education and Research. Vol. 36, No. 1 pp. 55-57. Retrieved from http://www.pu.edu.pk/images/journal/ier/PDF-FILES/4 Jabeen,\%20Qayyum\%20\&\%20Omar_V36-no12014.pdf

Java, J., et al. (2016). Gendered Illustrations in Philippine Textbooks. Asia Pacific Higher Education Research Journal, Vol. 3, Issue $\quad$ No. $1 . \quad$ Retrieved from http://po.pnuresearchportal.org/ejournal/index.php/apherj/article/viewFile/204/146

Joshi, A., et al. (2015). Gender Research in AMJ: AN Overview of Five Decadesof Empirical Research and Calls to Action. Retrieved from https://journals.aom.org/doi/abs/10.5465/amj.2015.4011

Kim, J., et al. (2016). FORUM: A Model Of Gender Inequality and Economic Growth. Retrieved from https://archive.intereconomics.eu/year/2017/1/gender-inequality-and-growth-in-europe/

Klasen, S., et al. (2017). FORUM: Gender Inequality and Growth in Europe. Retrieved from https://archive.intereconomics.eu/year/2017/1/gender-inequality-and-growth-in-europe/

Lindsey, L. (2016). Gender Roles: A Sociological Perspectives Fourth Edition. Pearson Prentice Hall in Upper Saddle River, N.J . U.S.A. Retrieved from https://pubs.aeaweb.org/doi/pdf/10.1257/0895330053148010

Lips, H. (2014). Sex and Gender. McGraw-Hill Education; 6 Edition. U.S.A. ISBN-10: 0073405531

Mayhew, A. (2016). Gender Gap Growing In Teaching Profession. Standford: Graduate School of Education. Retrieved from https://ed.stanford.edu/in-the-media/gender-gap-growing-teaching-profession-cites-thomasdee-research

Maniquiz, R. (2005). World Survey on The Role Of Women In Development 2014: Gender Equality And Sustainable Development. United Nations' Women. Retrieved from https://sustainabledevelopment.un.org/content/documents/1900unwomen_surveyreport advance 16oct.pdf

Miller, D. (2017). Stereotypes Can Hold Boys Back in School, Too. The Conversation. Retrieved from https://theconversation.com/stereotypes-can-hold-boys-back-in-school-too72035http://psycnet.apa.org/buy/1999-11924-002

Miske, S., et al. (2016). Gender Mainstreaming in Education at The Level of Field Operations: The Case of CARE USA's Indicator Framework. Taylor and Francis Online Publications. Retrieved from https://doi.org/10.1080/03057925.2010.490367

Olian, J., et al. (2016). The Impact of Applicant Gender Compared to Qualifications on Hiring Recommendations: A Meta-Analysis of Experimental Studies. Retrieved from https://www.sciencedirect.com/science/article/pii/0749597888900258

Oakley, A. (1972). Sex, Gender, and Society.Scientific Research: An Academic Publisher. London, UK. Retrieved

from https://www.scirp.org/(S(i43dyn45teexjx455qlt3d2q))/reference/ReferencesPapers.aspx?ReferenceID=1377 666

Ogalinda, M. (2017). Gender Bias Noted in K to 12 Books. Sun Star Philippines-Baguio. Retrieved from https://www.sunstar.com.ph/article/142287

Okarafur, P., et al. (2014). Inspiring Women's Participation in Technical, Vocational Education and Training for Sustainable Development in Africa. NAM Institute of the Empowerment of Women (NIEW). Journal vol. 6. Retreived https://www.academia.edu/38117386/INSPIRING_WOMENS_PARTICIPATION_IN_TECHNICAL_VO CATIONAL_EDUCATION_AND_TRAINING_FOR_SUSTĀINABLE_DEVELOPMENT_IN_AFRICA? auto $=$ download

Okpakwu, O., et al. (2014). Gender Equality in Schools: Implications for the Curriculum, Teaching and Classroom Interaction. Journal of Education and Practice, Vol.5, No.32. Paper: ISSN 2222-1735 Online: 
ISSN 2222-288X

Sumasad C. \& Tuazon, A. (2016). Gender and Development (GAD) Awareness in Higher Education Institution. International Journal of Educational Science and Research (IJESR), Vol. 6, Issue 3. Retrieved from https://papers.ssrn.com/sol3/papers.cfm?abstract_id=2838156

Torres, A., et al. (1994). Gender and Development: Making the Bureaucracy Gender-Responsive. Philippine Commission on Women. Philippines. Retrieved from https://ibrary.pcw.gov.ph/sites/default/files/Gender\%20and\%20development\%20making\%20the\%20burea ucracy\%20gender-responsive.pdf

Unger, R. (1979). Toward a Redefinition of Sex and Gender. Research Gate. Retrieved from DOI: 10.1037/0003-066X.34.11.1085

Online: https://www.researchgate.net/publication/232528550_Toward_a_redefinition_of_sex_and_gender

Winther, T., et al. (2011). Research Topic: Gender and Development. Retrieved from https://www.sum.uio.no/english/research/subjects/gender-and-development/

Wulansari, S. (2013). Gender Inequality Perception: A Comparative Study of Women in Japan and Indonesia. Retrieved from https://ricas.ioc.utokyo.ac.jp/aasplatform/achivements/pdf/2013 ab_16.pdf

\section{MAGAZINES/ NEWSPAPERS}

Llego, M. (2017). Deped Order: Gender-Responsive Basic Education Policy. Teacher.Ph. Retrieved from https://www.teacherph.com/gender-responsive-policy/

Philippine Commission on Women (PCW), (2006). Pananaw: National Women's Month 2006 (The Official Newsletter of the Philippines Center for Women's Studies). Special Issue Vol. XVI No. 2. Page 6.

Philippine Commission on Women (PCW), (2007). Pananaw: National Women's Month 2006 (The Official Newsletter of the Philippines Center for Women's Studies). Special Issue Vol. XVI No. 2. Page 6.

Sun.Star Pampanga (2017). Gender, Development Lessons Integrated in DepEd Curriculum. Press Reader. Retrieved from https://www.pressreader.com/genderanddevelopment

SPOT.Ph. (2017). Gender Bias and Discrimination. Retrieved from https://www.spot.ph/newsfeatures/the-latestnews-features/70919/department-education-textbooks-a00171-20170727-lfrm

UNESCO, (2016). Education 2030 Incheon Declaration: Towards Inclusive and Equitable Quality Education and Lifelong Learning for All. South Korea Retrieved from http://uis.unesco.org/sites/default/files/documents/education-2030-incheon-framework-for-actionimplementation-of-sdg4-2016-en 2.pdf

\section{E. ELECTRONIC SOURCES}

Feminist Social Theory. Social Theory Re-wired. Retrieved from http://routledgesoc.com/profile/feminist-socialtheory

Global Media Monitoring Project (GMMP), (2010). What Gender for Information? Final Report of (GMMP 2010 for The French-Speaking Community Of Belgium. Retrieved from https://eige.europa.eu/news/gender-mainstreaming-helping-build-more-equal-society

ILO (2000). ABC of Women Worker's Rights and Gender Equality. International Labor Organization, Geneva.

Learning English (2017). How to Identify Gender Inequality in Teaching Materials. Retrieved from https://learningenglish.voanews.com/a/how-to-identify-gender-inequality-in-teachingmaterials/3996027.html

NCRFW (2004). Gender Issues and Gender Equality Results. Philippine Commission on Women. Retrieved from http://pcw.gov.ph/sites

Philippine Commission on Women (PCW), (2017). Gerl Ka Ba? Retrieved from http://pcw.gov.ph/sites/default/files/documents/resources/gerl_ka_ba.pdf

The RNIJ Foundation Women (2015). ${ }^{-}$Feminism. Retrieved from https://rinj.org/feminism/?gclid=EAIaIQobChMIx_jsjpGN4QIVxQ0rCh1zjgiJEAAYAiAAEgKPpvD_BwE

The Millennium Development Goals Report 2015. United Nations, New York. Retrieved from http://www.un.org/millenniumgoals/2015_MDG_Report/pdf/MDG\%202015\%20rev\%20(July\%201).pdf

F. OTHERS: LAWS, MEMORANDUM, ETC.

DO 32, s. 2017- Gender-Responsive Basic Education Policy. Department of Education. Retrieved from http://www.deped.gov.ph/2017/06/do-32-s-2017-gender-responsive-basic-education-policy/

Republic Act 9710 (R.A 9710) - Magna Carta of Women. Philippine Commission on Women. Retrieved from https://pcw.gov.ph/law/republic-act-9710

Universal Declaration of Human Rights (UDHR). Retrieved from http://www.un.org/en/udhrbook/pdf/udhr_booklet_en_web.pdf

Convention on the Elimination of All Forms of Discrimination Against Women (CEDAW). Retrieved from 
http://www.un.org/womenwatch/daw/cedaw/

UNCHR, (2014). Gender Stereotypes and Stereotyping and Women's Rights. Women's Rights and Gender Section, OHCHR Research and Right to Development Division Rule of Law, Equality and NonDiscrimination Branch. Geneva.

Women's EDGE Plan 2013-2016, (2014). Women's Empowerment, Development and Gender Equality Plan 2013-2016. Philippine Commission on Women and UN Women. Philippines.

Memorandum Circular No. 2011-01. GAD Focal Point System Guidelines. Philippine Commission on Women. Retrieved from https://pcw.gov.ph/law/pcw-memorandum-circular-no-2011-01

Republic Act 7192 (RA 7192) - Women in Development and Nation Building Act. Philippine Commission on Women. Retrieved from https://pcw.gov.ph/law/republic-act-7192

DepEd Order No. 63, s 2012. Guidelines on the Preparation of Gender and Development (GAD) Plans, Utilization of GAD Budgets, and Submission of Accomplishment Reports. Retrieved from http://www.deped.gov.ph/2012/06/20/do-63-s-2012-guidelines-on-the-preparation-of-gender-anddevelopment-gad-plans-utilization-of-gad-budgets-and-submission-of-accomplishment-reports/ 